\title{
1978 - 2018: German Society of Ultrasound in Medicine (DEGUM) - 40 years of success
}

\author{
1978 - 2018: 40 Jahre Erfolgsgeschichte der Deutschen Gesellschaft für Ultraschall in der \\ Medizin (DEGUM)
}

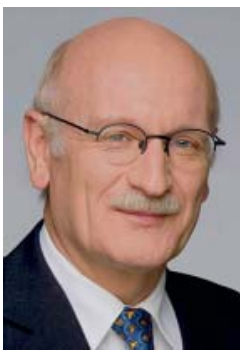

Prof. Dr. med. Prof. h.c. E. Merz
Correspondence

Prof. Dr. med. Prof. h. c. E. Merz DEGUM President 2006-2008

Center for Ultrasound and Prenatal Medicine,

Steinbacher Hohl 2-26, 60488 Frankfurt am Main

merz.eberhard@web.de

Bibliography

DOI https://doi.org/10.1055/a-0571-8489

Published online: 2018

Ultraschall in Med 2018; 39: 129-131

(c) Georg Thieme Verlag KG, Stuttgart · New York

ISSN 0172-4614
The German Society of Ultrasound in Medicine was created from the German Working Group for Diagnostic Ultrasound (DAUD) in 1978. The latter was founded in 1971 by just 15 scientists from the fields of neurology, neurosurgery, trauma surgery, gynecology and obstetrics, internal medicine, oral and maxillofacial surgery, and physics and was registered with the registration office in 1972 [1]. In 1976, it was decided at the annual ultrasound convention in Heidelberg to combine the yearly conventions of the German, Austrian (ÖGUM), and Swiss (SGUM) ultrasound societies into one Dreiländertreffen to be held on a rotating basis in the three countries. Given the growing number of members, the decision was made at the DAUD member meeting during the first Dreiländertreffen in Vienna on 12/8/ 1977 to rename the DAUD the German Society of Ultrasound in Medicine effective 7/5/1978 [2]. While the number of members was still only 152 in 1978, it has continuously increased since then with a total of 10647 by the end of 2017 ( Fig. 1). Today, the German Society of Ultrasound in Medicine (DEGUM) is not only one of the largest scientific medical societies in Germany but is also one of the largest ultrasound societies worldwide. It is comprised of sections and working groups.

From the beginning DEGUM's goal was to achieve a professional training standard for physicians in the field of diagnostic ultrasound by means of congresses, continuing education events, and continuing education courses/seminars. In the last 40 years, DEGUM has organized 14 Dreiländertreffen in Germany, 3 of these in cooperation with Euroson ( $\triangleright$ Table 1 ), as well as numerous continuing education courses.

In 2011 the ultrasound academy was founded as a DEGUM affiliate. It helps the course instructors of the DEGUM sections and working groups implement DEGUM-certified ultrasound courses and continuing education in ultrasound. The academy provides corresponding information regarding all DEGUM-certified courses via the course portal [3].

Well-trained ultrasound users can acquire a DEGUM certificate in all sections and working groups as proof of their qualification. The 3-level concept [4] that was established in diagnostic ultrasound in obstetrics already in the early $1980 \mathrm{~s}$ has since been adopted by all DEGUM sections/working groups as the corresponding qualification level concept.

Within the last years, DEGUM's Internet presence has also been completely redesigned [3]. All important DEGUM-related information is clearly listed in corresponding columns. To enable as many patients as possible to profit from professional diagnostic ultrasound services, the names of certified physicians are listed on the DEGUM website according to area of specialization, level of qualification and location, allowing patients to perform a simple search.

The establishment of the European Journal of Ultrasound as a journal for members of the three German-speaking ultrasound societies in 1980 by R. Müller (SGUM), E. Reinold (ÖGUM) and G. Rettenmaier (DEGUM) marked a further milestone in the field of ultrasound. With 15000 copies per issue, the journal is not only a successful mix of scientific articles and certified continuing education articles but is also one of the highest ranked imaging journals internationally.

DEGUM's collaboration with the Austrian Society of Ultrasound in Medicine (ÖGUM) and the Swiss Society of Ultrasound in Medicine (SGUM) has resulted not only in the annual Dreiländertreffen but also an intensive exchange of ideas in the fields of science and continuing education. Together with EUROSON, international communication is also maintained.

The editors of the European Journal of Ultrasound wish the German Society of Ultrasound in Medicine great success in the coming 
- Table 1 Dreiländertreffen (DLT) in Germany (modif. according to DEGUM Internet portal [3]).

- Tab.1 Dreiländertreffen (DLT) in Deutschland (Modif. nach DEGUM-Internetportal [3]).

\begin{tabular}{|l|l|l|l|l|}
\hline DLT & EUROSON & Date/Datum & Location/Ort & President/Präsidenten \\
\hline 40 th & & $10 / 26-29 / 2016$ & Leipzig & A. Hagendorff/O. H. Gilja \\
\hline 37 th & 25th & $10 / 9-12 / 2013$ & Stuttgart & A. Schuler/F. Piscaglia \\
\hline 34 th & & $10 / 20-23 / 2010$ & Mainz & E. Merz \\
\hline 31 st & 19th & $10 / 24-27 / 2007$ & Leipzig & V. Keim \\
\hline 28 th & & $10 / 6-9 / 2004$ & Hannover & M. Gebel \\
\hline 25 th & & $9 / 26-29 / 2001$ & Nürnberg & R. Goerig/N. Gritzmann/S. Tercanli \\
\hline 23 rd & 11 th & $9 / 26-29 / 1999$ & Berlin & B. Frentzel-Beyme/D. Nürnberg \\
\hline 21 st & & $10 / 1-4 / 1997$ & Ulm & B. Widder/K. Beck/N. Gritzmann \\
\hline 19 th & & $10 / 12-14 / 1995$ & Dresden & A. Bunk/J. E. Erk \\
\hline 16 th & & $10 / 21-24 / 1992$ & Karlsruhe & G. v. Kaik \\
\hline 13 th & & $10 / 4-7 / 1989$ & Hamburg & B. Hackelöer/G. v. Klinggräff/J. Gebhardt \\
\hline 10 th & & $10 / 1-5 / 1986$ & Bonn & M. Hansmann/D. Koischwitz/G. Trier \\
\hline 7th & & $9 / 25-28 / 1983$ & Erlangen & H. Lutz \\
\hline 4 th & & $5 / 14-17 / 1980$ & Böblingen & G. Rettenmaier \\
\hline & & & \\
\hline
\end{tabular}

years and continued fruitful collaboration with the cooperating ultrasound societies!

\section{8 - 2018: 40 Jahre Erfolgsgeschichte der Deutschen Gesellschaft für Ultraschall in der Medizin (DEGUM)}

Die Deutsche Gesellschaft für Ultraschall in der Medizin ging 1978 aus der Deutschen Arbeitsgemeinschaft für Ultraschalldiagnostik (DAUD) hervor. Letztere war bereits 1971 von gerade einmal 15 Wissenschaftlern aus den Fachgebieten Neurologie, Neurochirurgie, Unfallchirurgie, Gynäkologie u. Geburtshilfe, Innere Medizin, ZMK und Physik gegründet und 1972 beim Registergericht eingetragen worden [1]. Schon 1976 hatte man dann auf der Ultraschall-Jahrestagung in Heidelberg beschlossen, die jährlichen Treffen der deutschen, österreichischen (ÖGUM) und schweizerischen (SGUMB) Ultraschallverbände fortan als deutschsprachiges Dreiländertreffen gemeinsam und abwechselnd in den drei Ländern zu veranstalten. Bei deutlicher Zunahme der Mitgliederzahlen wurde dann auf der Mitgliederversammlung der DAUD während des ersten Dreiländertreffens in Wien am 8.12.1977 beschlossen, die DAUD mit Wirkung vom 5.7.1978 in Deutsche Gesellschaft für Ultraschall in der Medizin umzubenennen [2]. Während die Mitgliederzahl 1978 noch bei 152 lag, ist diese in den Folgejahren kontinuierlich angestiegen und lag Ende 2017 bei 10647 ( $\triangleright$ Abb. 1). Die Deutsche Gesellschaft für Ultraschall in der Medizin (DEGUM) gehört heute nicht nur zu den größten medizinischwissenschaftlichen Gesellschaften in Deutschland, sondern auch zu den größten Ultraschallgesellschaften weltweit. Insgesamt ist sie in Sektionen und Arbeitskreise aufgegliedert.

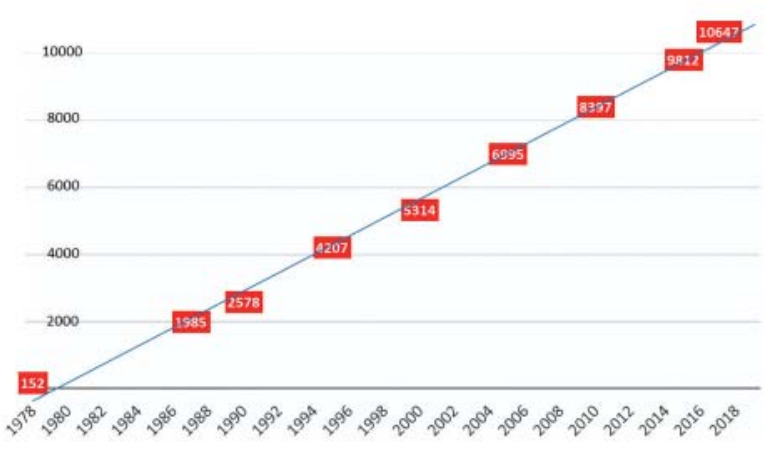

- Fig. 1 Number of DEGUM members from 1978 to 2017 with trend line.

- Abb. 1 Entwicklung der DEGUM-Mitgliederzahlen in den Jahren 1978 - 2017 incl. Trendlinie.

Ziel der DEGUM war es von Anfang an, durch Kongresse, Fortbildungsveranstaltungen und Fortbildungskurse/-seminare einen qualifizierten Ausbildungsstandard der Ärzte/Ärztinnen auf dem Gebiet der Ultraschalldiagnostik zu erzielen. Innerhalb der letzten 40 Jahre wurden von der DEGUM nicht nur 14 Ultraschall-Dreiländertreffen in Deutschland organisiert, drei davon in Kombination mit Euroson ( $\vee$ Tab. 1), sondern auch eine Vielzahl von Fortbildungskursen.

2011 wurde die Ultraschall-Akademie als Tochtergesellschaft der DEGUM gegründet. Sie unterstützt die Kursleiter der Sektionen und Arbeitskreise der DEGUM bei der Durchführung von DEGUM-zertifizierten Ultraschallkursen und Fort- und Weiterbil- 
dungen zum Ultraschall. Entsprechende Informationen zu allen DEGUM-zertifizierten Kursen stellt die Akademie in Ihrem Kursportal zur Verfügung [3].

In allen Sektionen und Arbeitskreisen können gut ausgebildete Ultraschallanwender zum Nachweis ihrer Qualifikation ein DEGUM-Zertifikat erwerben. Das in der geburtshilflichen Ultraschalldiagnostik bereits zu Beginn der 80er-Jahre etablierte 3-Stufenkonzept [4] wurde in der Zwischenzeit von allen DEGUM-Sektionen/Arbeitskreisen als entsprechendes QualifikationsStufenkonzept eingeführt.

Innerhalb der letzten Jahre wurde auch der Internetauftritt der DEGUM komplett neu gestaltet [3]. Hier werden alle Informationen, die innerhalb der DEGUM von Bedeutung sind, übersichtlich in entsprechenden Rubriken aufgeführt. Damit möglichst viele Patienten/innen von einer qualifizierten Ultraschalldiagnostik profitieren können, werden die Namen der zertifizierten Ärztinnen und Ärzte auf den Internetseiten der DEGUM nach Fachgebiet, Stufenqualifikation und Wohnort entsprechend aufgelistet und können so von den Patienten/innen abgerufen werden.

Mit der Gründung der Zeitschrift Ultraschall in der Medizin als Mitgliederzeitschrift der drei deutschsprachigen Ultraschallgesellschaften im Jahr 1980 durch die Herausgeber R. Müller (SGUMB), E. Reinold (ÖGUM) und G. Rettenmaier (DEGUM) konnte schon frühzeitig ein weiterer Meilenstein auf dem Gebiet des Ultraschalls etabliert werden. Mit einer Auflage von 15000 Exemplaren pro Heft bietet die Zeitschrift heute nicht nur einen gelungenen Mix aus wissenschaftlichen Artikeln und einem zertifizierten Fortbildungsteil, sondern gehört unter den bildgebenden Zeitschriften international zu den am höchsten gerankten Journalen.

Im Verbund mit der Österreichischen Gesellschaft für Ultraschall in der Medizin (ÖGUM) und der Schweizerischen Gesellschaft für Ultraschall in der Medizin (SGUM) findet nicht nur das alljährliche Dreiländertreffen statt, sondern auch ein intensiver Austausch auf dem Gebiet der Wissenschaft und der Fortbildung. Gemeinsam mit der EUROSON wird auch die internationale Kommunikation gepflegt.

Die Herausgeber der Zeitschrift Ultraschall in der Medizin (European Journal of Ultrasound) wünschen der Deutschen Gesellschaft für Ultraschall auch für die kommenden Jahre viel Erfolg und eine weiterhin gute und freundschaftliche Zusammenarbeit mit den kooperierenden Ultraschallgesellschaften.

\section{References}

[1] Lutz H, Trier H-G. Zur Entwicklung der deutschen Ultraschallgesellschaften in der Medizin. 1. Teil: die DAUD. Ultraschall in Med 2015; 36: 401-402

[2] Lutz H. Zur Entwicklung der deutschen Ultraschallgesellschaften in der Medizin. 2. Teil: die DEGUM. Ultraschall in Med 2017; 38: 566- 568

[3] http://www.degum.de/index.html

[4] Hansmann M. Nachweis und Ausschluß fetaler Entwicklungsstörungen mittels Ultraschallscreening und gezielter Untersuchung - ein Mehrstufenkonzept. Ultraschall 1981; 2: 206-220 